\title{
Architecture_MPS
}

\section{Grassroots Agency: Participation and Conflict in Buenos Aires Shantytowns seen through the Pilot Plan for Villa 7 (1971-1975)}

Adriana Laura Massidda ${ }^{1, *}$

How to cite: Massidda, A. L. 'Grassroots Agency: Participation and Conflict in Buenos Aires Shantytowns seen through the Pilot Plan for Villa 7 (1971-1975).' Architecture_MPS, 2017, 12(1): 4. DOI:

https://doi.org/10.14324/111.444.amps.2017v12i4.001

Published: 1 December 2017

\section{Peer Review:}

This article has been peer reviewed through the journal's standard double blind peer-review, where both the reviewers and authors are anonymised during review.

\section{Copyright:}

(C) 2017, The Author(s). This is an Open Access article distributed under the terms of the Creative Commons Attribution License (CC-BY) 4.0 https://creativecommons.org/licenses/by/4.0/, which permits unrestricted use, distribution and reproduction in any medium, provided the original author and source are credited • DOI: https://doi.org/10.14324/111.444.amps.2017v12i4.001.

\section{Open Access:}

Architecture_MPS is a peer-reviewed open access journal. 


\title{
Title: Grassroots Agency: Participation and Conflict in Buenos Aires Shantytowns seen through the Pilot Plan for Villa 7 (1971-1975)
}

\section{Author: Adriana Laura Massidda}

\begin{abstract}
Architecture_media_politics_society. vol. 12, no. 4.
\end{abstract}
December 2017

Affiliation: Centro de Estudios Urbanos y Regionales, Consejo Nacional de Investigaciones Científicas y Técnicas, Buenos Aires, Argentina

\section{Abstract}

In 1971, after more than a decade of national and municipal policies aimed at the top-down removal of shantytowns, the Buenos Aires City Council approved the Plan Piloto para la Relocalización de Villa 7 (Pilot Plan for the Relocation of Shantytown 7; 1971-1975, referred to as the Pilot Plan hereinafter). This particular plan, which resulted in the construction of the housing complex, Barrio Justo Suárez, endures in the collective memory of Argentines as a landmark project regarding grassroots participation in state housing initiatives addressed at shantytowns. Emerging from a context of a housing shortage for the growing urban poor and intense popular mobilizations during the transition to democracy, the authors of the Pilot Plan sought to empower shantytown residents in novel ways by: 1) maintaining the shantytown's location as opposed to eradication schemes that relocated the residents elsewhere, 2) formally employing some of the residents for the stage of construction, as opposed to "self-help" housing projects in which the residents contributed with unpaid labor, and 3) including them in the urban and architectural design of the of the new housing.

This paper will examine the context in which the Pilot Plan was conceived of as a way of re-assessing the roles of the state, the user, and housing-related professionals, often seen as antagonistic. The paper argues that residents' fair participation and state intervention in housing schemes are not necessarily incompatible, and can function in specific social and political contexts through multiactor proposals backed by a political will that prioritizes grassroots agency.

DOI: $10.14324 / 111.444 . a m p s .2017 v 12 i 4.001$, (c) 2017, The Author. This is an Open Access article distributed under the terms of the Creative Commons Attribution License, which permits unrestricted use, distribution, and reproduction in any medium, provided the original author and source are credited. 


\title{
Title: Grassroots Agency: Participation and Conflict in Buenos Aires Shantytowns seen through the Pilot Plan for Villa 7 (1971-1975)
}

\author{
Author: Adriana Laura Massidda
}

Architecture_media_politics_society. vol. 12, no. 4 .

December 2017

\section{Introduction}

In 1971, after more than a decade of national and municipal policies aimed at the top-down removal of shantytowns, the Buenos Aires City Council approved the Plan Piloto para la Relocalización de Villa 7 (Pilot Plan for the Relocation of Shantytown 7; 1971-1975, referred to as the Pilot Plan hereinafter). This particular plan, which resulted in the construction of the housing complex, Barrio Justo Suárez, endures in the collective memory of Argentines as a landmark project regarding grassroots participation in state housing initiatives addressed at shantytowns. Emerging from a context of a housing shortage for the growing urban poor and intense popular mobilizations during the transition to democracy, the authors of the Pilot Plan sought to empower shantytown residents in novel ways by: 1) maintaining the shantytown's location as opposed to eradication schemes that relocated the residents elsewhere, 2) formally employing some of the residents for the stage of construction, as opposed to "self-help" housing projects in which the residents contributed with unpaid labor, and 3) including them in the urban and architectural design of the of the new housing.

This approach responded to key demands of the shantytown's population, their local committees, and umbrella organizations, with whom the architects of the Pilot Plan had previously collaborated. At the same time, the Pilot Plan reflected the contemporary debate amongst architects, planners, and policy makers regarding the role of the user, which continues to this day. It is possible to identify here two conflicting views on the scope and the political implications of users' participation in housing production: one which conceives of such participation as one more aspect within a general process of empowerment of the working classes, and the other, which inscribes it within a political project aimed at preserving the status quo either directly or indirectly, by limiting user participation to the construction of housing while 


\section{Amps}

excluding them from the planning and design phases. It is worth mentioning that the latter approach also considers politics to be beyond the scope of architects and planners. The Pilot Plan represents the former approach, emphasizing the importance of residents' participation as a driving force for social change. ${ }^{1}$

This paper will examine the context in which the Pilot Plan was conceived of as a way of re-assessing the roles of the state, the user, and housing-related professionals, often seen as antagonistic. The paper argues that residents' fair participation and state intervention in housing schemes are not necessarily incompatible, as will be shown through the unique example of the Pilot Plan. At the same time, it is understood that the political conditions necessary for state departments, agents, and residents to collaborate towards social change present themselves only on rare occasions. The research presented here will offer a twofold contribution to the specialized literature. First, it will contribute to the contemporary, international discussion on the politics of user participation in architectural design through the analysis of a historical case study in Argentina. Second, it will contribute to the specialized literature on urban informality and state-led housing initiatives for shantytowns by introducing the Pilot Plan to an international English-speaking audience. Despite being a well-known example of grassroots participation amongst Argentine architects, studies devoted to the Pilot Plan in Spanish are extremely scarce, ${ }^{2}$ and there is currently no research about the Pilot Plan or its protagonists published in English.

\section{Argentine Politics, Housing, and "Eradication" Schemes}

The Pilot Plan was designed by an independent, interdisciplinary team led by architects Osvaldo Cedrón and Alberto Compagnucci during the last years of the military dictatorship "Revolución Argentina" (1966-1973). The political landscape of Argentina at the time was one marked by mass protests, demonstrations, and both peaceful and violent social movements against the dictatorship. The protests denounced the curtailment of workers' rights, the decline in real incomes, the general climate of oppression, and not least, the proscription of Peronism (formally known as the Justicialist Party from 1947 onwards), the political party of Juan Domingo Perón (President of Argentina, 1946-1952, 1952-1955). Perón's second elected term as president had been interrupted in 1955 by a coup d'état, the Revolución Libertadora, which banned his political party and forced him into exile. However, Perón remained extremely popular amongst Argentine working classes for the wide range of public projects he implemented during his tenure as president from increasing access to social security and social healthcare programs, to improving working conditions and raising real wages. His approach to governance generated a discourse around the use of public space, and raised the morale of millions of working-class Argentines, giving them a sense of political empowerment. ${ }^{3}$ 


\section{Amps}

Throughout Perón's administration, however, Argentine shantytowns grew at a rapid pace due to the industrialization of the Argentine economy and the consequential influx of migrants leaving the countryside in search of stable, paid jobs in cities that were unprepared to receive such a rapid influx of population. While Perón's government did not articulate a specific policy towards the shantytowns, it did focus on offering mass social housing and accessible state mortgages. ${ }^{4}$

The Revolución Libertadora that overthrew Perón (not to be confused with the Revolución Argentina) was the first to address Argentine shantytowns as a specific target for government policy. It did so by starting from the assumption that the role of the state was to "eradicate" them, demolishing the existing shacks and relocating their residents to purpose-built social housing. It also assumed that shantytown residents were largely responsible for their poor living conditions, and that the layout and the design of new housing could change their social habits. ${ }^{5}$ Financial constraints and changes in policy direction meant that only a small proportion of the program was implemented, however. ${ }^{6}$ Throughout the rest of the 1950s and the 1960 s the government's interest in eradication was maintained, though there were brief instances under the governments of Arturo Frondizi (President, 1958-1962) and Arturo Illia (President, 1963-1966), for example, in which local administrations or national departments provided free materials to residents who contributed to the housing projects with free labor. ${ }^{7}$

The Revolución Argentina, which put General Juan Carlos Onganía in power in 1966, represented a turning point in state policy towards shantytowns. Returning to the approach of the Revolución Libertadora, government action was exclusively one of eradication. An overarching official program of shantytown eradication was launched in Buenos Aires under the new regime, combining national funding and municipal implementation: the Plan de Erradicación de Villas de Emergencia (Shantytown Eradication Plan). "Eradication" included the forceful eviction of shantytown residents, sometimes through the use of military force, and their relocation to purpose-built social housing. The shantytown dwellings, meanwhile, were demolished. The new social housing complexes presented, in most cases, serious problems to the shantytowns' population. First, although subsidized, the housing unit prices were often too high for shantytown residents. ${ }^{9}$ While this may seem contradictory, governments were anxious to recover the funds invested in housing, and for this reason, rather than targeting those most in need - families with the lowest and most unstable incomes - they envisaged social housing users to be low income, but at the same time capable of making regular payments. Secondly, many of these complexes were located far from employment sources and, moreover, from essential public facilities such as schools, hospitals, or leisure areas. Even more worryingly, evicted shantytown residents were not offered permanent housing in most cases, and were instead housed in temporary shacks offered by the state, which, in effect replicated the problem. ${ }^{10}$ 


\section{Amps}

These eradication schemes, like those under the Revolución Libertadora, were based on a conception of the shantytown resident as indolent and therefore responsible for their poverty and the precarious conditions of their living environments. ${ }^{11}$ They also conveyed the underlying idea that shantytown dwellers followed cultural patterns that needed to be forcibly altered; however, rather than seeking to modify their behavior through housing design, they envisioned social re-programming as being carried out directly by social workers. In one of these documents, for example, it is stated that "the social environment of the villas miseria [. . .] contributes to worsening [residents'] natural tendencies and transforming these slums into permanent foci of epidemics and moral degradation: urgent action is required for the social re-adaptation of the majority of their inhabitants." 12

Shantytown organizations and advocates who dared to voice their opposition to these eradication initiatives were often harassed or silenced by other means. Local governments, for example, tried to intervene in shantytown committees' elections in order to promote leaders who adhered to their eradication plans, refusing all dialogue with committees that did not accept this procedure. ${ }^{13}$ Meanwhile, the police intensified their harassment of shantytown residents; it was not unusual, for example, for the most active residents to be arrested by police officers and retained in prison for short periods with no formal reasons, denouncements, or court procedures. ${ }^{14}$ The repression also reached external organizations. For example, on December 20, 1968, twentyone priests from the politically active Movimiento de Sacerdotes para el Tercer Mundo (Movement of Priests for the Third World) sent a formal letter to the Onganía requesting him to cease the eradication programs, and silently stood in front of the Casa Rosada, the official presidential residence, as a means of protesting. These priests, many of whom had worked in the villas miserias, continued their protests by distributing leaflets about their cause to passers-by in the adjacent Plaza de Mayo and by organizing hunger strikes around Buenos Aires. ${ }^{15}$ By January, those higher up in the hierarchy of the Catholic Church had issued a statement forbidding the priests to "participate in any public acts or distribute resolutions concerning the social, economic, or political order without prior authorization of the archbishop, Cardinal Primate Antonio Caggiano," who was a known supporter of Onganía.

In the midst of this rising tide of popular mobilizations, the military government was ultimately forced to make concessions in an attempt to pacify society, including lifting the proscription of Peronism, and holding open elections in $1973 .{ }^{16}$ It was in this highly turbulent period in which the Pilot Plan was conceived and eventually executed. The lead architect, Cedrón, presented the Pilot Plan to the municipal authorities, and it was unexpectedly approved in 1971 by Mayor Saturnino Montero Ruiz. Those who took part in the Plan perceived Ruiz's approval as motivated by his ambition to work with the then dictator Agustín Lanusse, who planned to run for the presidency during the transition to democracy. Montero Ruiz's policies towards shantytowns had up until that point followed those of the Revolución Argentina by locally 
implementing the eradication plan, which had become extremely unpopular. Thus, the mayor's support of the Pilot Plan could be read as an attempt to gain popular votes. ${ }^{17}$

Given the political context described above, the Pilot Plan represented a striking innovation as a state-sponsored initiative addressed at shantytowns. Rather than forcibly clearing the shantytown and evicting its residents, it proposed providing housing units where the villa was located (or, alternatively, in the closest available plot), and rather than excluding the residents, their participation was conceived of as the leading element in the design process. In the Pilot Plan for Villa 7, the professionals involved not only consulted the shantytown dwellers about the project and invited them to participate in its realization, but also physically moved their offices to the shantytown to work in a routine that allowed daily contact.

\section{Discussions on Self-Help and the Role of the User in the Cold War Era}

In parallel to the implementation of eradication policies in Argentina during the 1950s and 1960s, and the emergence of the Pilot Plan in the 1970s, a different and more conservative notion of user participation was being discussed and developed in inter-American agencies. Such discussion had stemmed from the idea of aided self-help and the early antecedent of the "land and utility" projects implemented in Puerto Rico in the early 1940s. Through these projects, the government purchased large tracts of undeveloped land in and around urban areas, and provided it with essential infrastructure before subdividing it and offering it for rent or sale to low-income families, who were then responsible for moving their old homes to the site or building new ones. ${ }^{18}$ Similar projects called "aided self-help subdivisions" were also put into practice in urban areas of Puerto Rico with smaller populations. However, on these government-provided parcels of land, the residents were expected to install the essential infrastructure, including potable water and sewage systems. ${ }^{19}$

Despite having a unique geopolitical landscape, the Puerto Rico programs that engaged residents in the construction of their housing served as inspiration for government-aided self-help programs in other parts of Latin America, particularly after the Second World War when the leaders of the US and Latin American countries made a united effort to create more formal systems of coordinating a wide range of inter-American activities. ${ }^{20}$ The role of users' participation was discussed with increasing interest amongst inter-American organizations composed of high-level government officials from the US and Latin America who organized a multitude of specialized conferences. Even though some of these institutions had only recently been established, the fact that they were mostly composed of people who were already in positions of great power in the US and Latin America made them extremely influential, as the ideas they brainstormed in conferences could be immediately put into 


\section{Amps}

practice. The Division of Housing and Planning of the OAS Inter-American Economic and Social Council (IA-EcoSoc) is a key example, and relevant to this paper.

The US interest in these projects must be understood in the context of the Cold War. Through these programs, the US sought to simultaneously maintain or improve US-Latin American relations and business activity while also containing the increasing interest in communism throughout Latin America, which was perceived as a threat to established trade relations. While Latin American governments had more obvious interests in alleviating their respective housing crises, identifying economically viable solutions to the problems of shantytowns - namely in the form of these self-help housing programs was a way to minimize discontent amongst the growing urban poor. The increasing importance given to the principle of "self-help" was made evident through the establishment of the Centro Interamericano de la Vivienda (CINVA; also known as the Inter-American Housing Center) at the National University of Colombia in 1951 through the OAS Program of Technical Cooperation. ${ }^{21}$ CINVA quickly developed a reputation amongst Argentine professionals interested in self-construction, as one of the leading Argentine modernist architects at the time, Ernesto Vautier, had worked there between 1953 and $1961 .{ }^{22}$ The research projects at CINVA were heavily influenced by the aforementioned Puerto Rican "land and utilities" projects, and were known for their experimentation in the technical aspects of housing construction and finance. CINVA played a crucial role by training Latin American planners in self-help. ${ }^{23}$

Later, at the Tenth Inter-American Conference (Caracas, 1954), the IA-EcoSoc presented a report analysing the incongruence between the costs of construction and the residents' incomes. ${ }^{24}$ The report celebrated self-help housing initiatives and low-interest loans funded internally by their respective countries, and insisted on the standardization of materials as a way of reducing building costs. However, despite acknowledging the fact that economic inequality was the main cause of the housing shortage in Latin America, the IA-EcoSoc considered the economic, social, and political issues as beyond its scope, and focused only on the technical aspects of housing production. A similar view can be found in the conclusions of the First Technical Meeting Inter-American Housing and Planning (Bogotá), organized by the IA-EcoSoc two years later, in 1956. It is noteworthy, then, that the contributions offered by these agencies in relation to users' participation implied the perpetuation of the status quo in structural social and economic terms.

Though funding these new housing programs in Latin America was a continual source of discussion amongst the inter-American agencies and Latin American government representatives, the US had been reluctant to give financial aid. This had been a point of contention that became particularly evident in the aforementioned Tenth Inter-American Conference, where Latin-American countries, overwhelmed with growing poverty, sought financial aid, while the US aimed at curbing the advance of communism without 
committing any funding. ${ }^{25}$ The increasing anxiety in the US after the Cuban Revolution (1953-1959), when Fidel Castro aligned himself with the Soviet Union, however, led to the launch of an inter-American program of financial aid called the Alliance for Progress in 1961. This program, administered by the Inter-American Development Bank, offered \$20 billion in loans to LatinAmerican governments over a period of ten years, under the condition that Latin-American countries would contribute $\$ 80$ billion over the same period of time. The financial commitment of the US was with the intention of securing their business and trade interests there as well as of combating the rising civil unrest and anti-American sentiment in Latin America. ${ }^{26}$ According to the Encyclopedia of the Inter-American System, the Alliance for Progress "sought national development and stability through political democratization, economic growth, and social reform. The armed forces were to focus on counterinsurgency, not only through military force but civic action programs (such as literacy and technical training, infrastructure projects, and other activities beneficial to civilians)." ${ }^{27}$ While representing improvements to eradication of housing schemes, once again the projects that would be funded through the Alliance for Progress had political motivations that were ultimately anti-revolutionary.

One of the Argentine housing projects partially funded by the Alliance for Progress included the Asistencia Técnica, Esfuerzo Propio y Ayuda Mutua (ATEPAM: literally, Technical Assistance, Own Effort and Mutual Help) - a program launched in 1962 which engaged users in the construction of their own housing. ${ }^{28}$ Their participation, however, was strictly limited to unpaid construction labor. The architectural projects and the distribution of land and construction materials were developed and administered centrally by the Instituto de la Vivienda de la Provincia de Buenos Aires (IVBA; Housing Institute of the Province of Buenos Aires), which was founded in 1956 for the purpose of "advising, coordinating and promoting private initiative for the acquisition and/or construction of housing." 29 The ATEPAM represents the main built antecedent for the Pilot Plan. Its director, Hilario Zalba (1912-1995), who also served as the President of the IVBA (1958-1962), was an architect and mentor to some of the authors of the Pilot Plan. ${ }^{30}$ Zalba also taught at the Faculty of Architecture and Urbanism of the National University of La Plata (FAU/UNLP), approaching the question of the role of the user from quite a different angle from that of the IA-EcoSoc. As early as 1947 Zalba and his team had stressed the importance of the social role of architecture, and the constant contact between its teaching and real-world issues such as social inequality. ${ }^{31}$ This represented an innovation in a context where most architectural curricula were inward looking, focused on discussions of architectural style. After 1961, Zalba's work in the FAU/UNLP was resumed by architects Juan Molina y Vedia and Marcos Winograd, known for their writings and activism in self-construction and housing. ${ }^{32}$ Quite importantly, however, the interdisciplinary methodology advocated by those at FAU/UNLP viewed the sociological and economics components 


\section{Amps}

differently. In contrast to the top-down approach, in which the goals were to change user habits and culture in order to preserve the existing political order, users' participation in design was addressed in relation to its potential to radically transform the social and economic structure. The main authors of the Pilot Plan, Cedrón and Compagnucci, together with other members of the team such as Ana Azzarri, were trained in this academic milieu.

At the international level, John F. C. Turner's works and writing had a notable influence on the ideas of Cedrón, Compagnucci, and their team's views in regards to grassroots participation in design. Turner was trained as an architect in 1950s' England, amidst the discourse surrounding the architectural vernacular, human scale, and the human aspects of architecture initiated by Team $10 .^{33}$ In the early 1960 s, Turner was invited to take part in a state housing project in Arequipa, Peru, where he became acquainted with the idea of self-help housing as it was conceived of in the Americas. ${ }^{34}$ Fascinated with Peruvian shantytowns, Turner celebrated residents' creativity and effectiveness in achieving their own housing solutions and became an advocate of self-construction, although not necessarily as organized by the state as inter-American agencies promoted. Rather, Turner believed in the de-centralization of housing decisions, and of government power generally. ${ }^{35}$ He became a central figure in the discussion about users' participation in the Americas by the mid-1970s, and was particularly influential in Argentine architectural circles. ${ }^{36}$

Perhaps what most deeply marked the formation of the architects who took part in the Pilot Plan, however, was their voluntary work at shantytowns, and their engagement with radicalized political movements in Argentina. Cedrón, in particular, was affiliated with the Frente Villero Peronista para la Liberación (FVLP; Peronist Shantytowns Front for Liberation), which later merged with the Movimiento Villero Peronista (MVP; Peronist Shantytowns Movement). These were shantytown movements strongly linked to Peronism that were created and developed by local residents who opposed shantytown eradication plans and advocated for state support for shantytown improvements, and the creation of shantytown construction cooperatives, amongst other things. ${ }^{37}$ Cedrón's connection to them meant that he was campaigning for residents' participation in shantytown improvements at the same time as advocating lifting the ban on Peronism in politics. The design team's political identification with Peronism says something about their conception of participation. Peronism had offered the working class a say in political debates, and its banning in 1956 meant a removal of its supporters, mostly workers, from political participation. By conceiving the Pilot Plan from this political angle, Cedrón and the team were interweaving design and political engagement.

\section{The Housing Design of Villa 7}

The design team's perspective on participation influenced the development of the Pilot Plan in several concrete ways. First, from the outset of the program, 


\section{Amps}

the team aimed to get closer to the users, transforming them into participants - although not the sole participants - in all the stages of development of the project. In this way, the Pilot Plan was different from most self-help programs, where users only contributed with labor. It was also different from programs where architects merely drew what residents drafted. In addition, rather than using the offices they had been offered at the municipal headquarters, the members of the design team recycled an abandoned wagon into an improvised studio and carried out the design process within the shantytown grounds. In fact, they were independent professionals who had been hired by the municipality for the Pilot Plan specifically, but who had their own ideas about how to carry out the Plan. This, in the longer run, led both to tensions and to friendships with members of staff who worked for the municipality. ${ }^{38}$ In the shorter term, it made the process of collaborative design dynamic and thorough.

The design that resulted from this collaboration showed significant design innovations in contrast to the more rigid models of the social housing projects of the time. Regarding the number of rooms, the units responded to the actual sizes of the families to be housed, not to abstract models. Up until this point, social housing units were frequently designed for generic nuclear families (couples with a number of children), ignoring the wide variety of households that populated shantytowns and tenements. ${ }^{39}$ In the shantytowns, in particular, it was common that families would live with relatives from different generations, or coming from the provinces, thus a single household would often include parents, children, grandparents, and/or aunts, uncles, and cousins. This led to a particularly wide range of units - a challenge in terms of design. Regarding the terraces, the design team sought to recreate in these the ground-floor courtyards that the residents had identified as one of the main reasons they preferred living in houses instead of flats. Given the number of families and the land available, density of the population made it impossible to offer houses instead of apartment units to the families. As a compromise, the flats incorporated parrillas (Argentine grills for barbeques) and large spaces for tables and chairs in their terraced entrances in an attempt to recreate some of the aspects and spatial qualities typical of the ground floor. Regarding the internal layout, internal corridors and partitions that often featured in more traditional middle-class housing designs were replaced with large, open spaces, as the families had specifically requested. Bedroom doors thus opened directly into the public spaces of the house. ${ }^{40}$

A second aspect that reflected the design team's engagement with the residents' needs was the priority given to the permanence of the families in the area. This position not only recognized the importance of the neighborhood's location in relation to the residents' jobs, but also the significance of the networks of solidarity between families built over time, which played an important role in relation to everyday survival, cooperation, and political self-organization. ${ }^{41}$ The significance of staying in their locations in order to retain these community ties had been a key part of shantytowns' struggles. 


\section{Amps}

Finally, the design team endeavored to hire as many residents as possible, and for this, it devised technological solutions capable of being performed by unskilled labor. The most important of these was a system of pre-fabricated hollow brick panels, which were assembled near the working site and used for the external walls, accelerating construction. This approach went handin-hand with residents' claim that social housing should be constructed by state-supported, shantytown-led companies as opposed to large construction companies that were typically contracted to build social housing when not using the unpaid labor of shantytown residents..$^{42}$ The residents who worked on the construction of Villa 7 were formally employed by the municipality at the request of the design team; in addition to being remunerated, they received employee benefits. ${ }^{43}$ In this way, the Pilot Plan can be read as an anticipated response to those criticisms focused on the exploitation of labor, normally addressed in the cases where the users' contribution was unpaid for being considered part of their own investment. Furthermore, in the Pilot Plan the payment system by installments was also agreed between the residents, the municipality, and the design team. ${ }^{44}$

\section{In the Longer Run}

The Pilot Plan represents a part of the debate about user participation in housing design that remains open: Who participates in the design process? To what extent do they participate? And who benefits from the process? Authors from Turner and Giancarlo de Carlo, in the 1960s and 1970s, to Peter Blundell Jones, Doina Petrescu, Jeremy Till and Camillo Boano today, have emphasized the importance of users' creativity to generate housing and urban transformations. ${ }^{45}$ Well-known and regarded contemporary architectural practices have also engaged in this discourse. Elemental (led by Alejandro Aravena), for example, claims to have developed a user-centered approach, while Nishat Awan, Tatjana Schneider, and Jeremy Till have explored the significance of the concept of agency for spatial production. ${ }^{46}$ On the other hand, the importance of the role of the state has been underlined by authors like Emilio Pradilla and Rod Burgess in the 1970s and 1980s. ${ }^{47}$ Their writings were a response to those of Turner and were motivated by the concern that an over-celebration of users' input could serve as an excuse for the retreat of the state and/or the exploitation of the users' labor. The Pilot Plan for Villa 7 shows, however, that government support and popular housing production are not necessarily incompatible, and that their respective roles in the project depend on the political conceptions that support it.

The initial conception of the Pilot Plan for Villa 7 by the leading architects as a pilot phase - that is, an experimental approach to be replicated in other shantytowns - was both a failure and a success. It can be considered a failure because, as explained earlier, the military dictatorship then in power had closed all channels for popular participation in shaping the design of housing and urban space, more generally. At the same time, it is possible to argue 
that it was successful, given the fact that the executed plan demonstrated the feasibility of integrating both the residents' and professionals' designs while keeping the parameters of cost, timing, and construction quality within the required standards. In addition, municipal employees who had only been exposed to planning methods employed in previous housing initiatives found a new way to intervene in the shantytowns and thoroughly engaged with this new approach. While the Pilot Plan was being implemented, for example, the Municipal Housing Institute developed a system called mesas de trabajo, or working boards, whereby residents and municipal members of staff regularly gathered to discuss solutions to the most pressing issues faced by shantytowns. This system was intended to scale up the Pilot Plan's participatory design process and captured the attention of the architectural profession beyond the dissemination of the Plan. ${ }^{48}$ In other words, despite not being able to immediately implement these new techniques, given the restrictions of the dictatorship, residents and specialists retained their knowledge of the successes of the Pilot Plan, with the hope of being able to use it within a different political landscape at some point in the future. ${ }^{49}$

The Pilot Plan stands today as an example of participatory design that remains unique in its incorporation of all the residents into the decisionmaking process. The phrase "participatory design" has become ubiquitous and arguably overused today, employed to refer to processes that range from consultation to self-construction. In some national contexts, for example, "participation" is a formal requirement of planning processes, and yet very often it scarcely extends beyond informed consent and consultation. ${ }^{50} \mathrm{By}$ looking at a historical example in Latin America which remains yet unparalleled in the depth of its commitment to participatory practices, this article has sought to bring fresh light to a long-term discussion which is far from being exhausted. More specifically, the article has sought to highlight the fact that by including both professional and residents' decisions at each stage of the project in a politically conscious way, and by formally remunerating the residents for their labor in the production of the housing, it is possible for residents, technicians, and state to collaborate jointly in the production of housing. In other words, the Pilot Plan for Villa 7 can be read as a demonstration that residents' creativity and state intervention are not necessarily opposing forces but rather, different perspectives that can be reconciled and articulated through a proposal that stems from user demands coupled with political will. In a world where urban poverty and housing shortages continue to exist, joint efforts to find solutions to these problems within each unique political context are more than necessary.

\section{Notes}

1 "Para construir las casas de los villeros nadie mejor que el pueblo villero," El Descamisado 32 (December 24, 1973), 21; Osvaldo Cedrón, "Villa 7 -Plan Piloto de Realojamiento: Balance de una experiencia," in "El techo," special issue, 


\section{Amps}

Revista de Arquitectura, 198 (2000): 108-111; Alicia Ziccardi, "El tercer gobierno peronista y las villas miseria de la ciudad de Buenos Aires (1973-1976)," Revista Mexicana de Sociología 46, no. 4 (1984): 145-172; Patricia Dávolos, Marcela Jabbaz, and Estela Molina, Movimiento villero y estado (1966-1976) (Buenos Aires: Centro Editor de América Latina, 1987).

2 The only extensive study in Spanish is Romina Barrios's unpublished dissertation, "Participación y hábitat popular. Análisis de una experiencia piloto: El Plan de Realojamiento de la Villa 7 en Mataderos, Ciudad de Buenos Aires, entre 1971 y 1975" (Master's thesis, Universidad de Buenos Aires, 2011).

3 Daniel James, Resistance and Integration: Peronism and the Argentine Working Class, 1946-1976 (Cambridge: Cambridge University Press, 1994), 7-40; Liliana de Riz, and Juan Carlos Torre, "Argentina since 1946," in The Cambridge History of Latin America, ed. Leslie Bethell (Cambridge: Cambridge University Press, 1991), VIII, 73-101. See in particular, pp. 73-93.

4 Rosa Aboy, "'The Right to a Home': Public Housing in Post-World War II Buenos Aires," Journal of Urban History 33 (2007): 493-518; Anahi Ballent, Las huellas de la politica: Vivienda, ciudad, peronismo en Buenos Aires, 1943-1955 (Buenos Aires: Universidad Nacional de Quilmes/Prometeo, 2005).

5 Comisión Nacional de la Vivienda, Plan de Emergencia: Informe elevado al Poder Ejecutivo Nacional (Buenos Aires: Ministerio de Trabajo y Previsión, 1956). See also, Adriana Massidda, "The Plan de Emergencia (1956): Housing Shortage in Buenos Aires Then and Now," Scroope: The Cambridge Architecture Journal 21 (2012): 42-51.

6 Comisión Nacional de la Vivienda, Informe de la Comisión Nacional de la Vivienda sobre su actuación y Plan Integral elevado al Ministerio de Trabajo y Previsión, vol. 1 (Buenos Aires: Ministerio de Trabajo y Previsión, 1957); Oscar Yujnovsky, Claves politicas del problema habitacional argentino (1955-1981) (Buenos Aires: Grupo Editorial Latinoamericano, 1984), 85-122; Adriana Massidda, "Urban Planning and Undertakings upon Informal Settlements in Buenos Aires: A 1955 1959 Review" (MPhil. thesis, University of Cambridge, 2011).

7 Adriana Laura Massidda, "Shantytowns and the Modern City: Examining Urban Poverty in South-Western Buenos Aires (1958-1967)" (PhD thesis, University of Cambridge, 2016).

8 Ministerio de Bienestar Social, Plan de Erradicación de las Villas de Emergencia de la Capital Federal y el Gran Buenos Aires: Primer programa - erradicación y alojamiento transitorio (Buenos Aires, Ministerio de Bienestar Social, 1968).

9 Comisión Municipal de la Vivienda, Centro Urbano Integrado Parque Almirante Brown: Solicitud de préstamo al Banco Interamericano de Desarrollo, vol. 1 (Buenos Aires: Municipalidad de la Ciudad de Buenos Aires, 1965); "C.M.V. Villas de Emergencia" 1970, 9; Acta n 111/70 (Comisión Municipal de la Vivienda) 1970.

10 "Esas casas son suyas! Ocupantes del Barrio Almirante Brown,” Nuestra Palabra (March 5, 1963); "Desalojos: Última hazaña de la dictadura," El Descamisado 2 (May 29, 1973); Yujnovsky, Claves, 163-169; Eduardo Blaustein, Prohibido vivir aquí: una historia de los planes de erradicación de villas de la última dictadura 


\section{Amps}

(Buenos Aires: Comisión Municipal de la Vivienda, 2001), 27-37; Massidda, "Plan de Emergencia."

11 Hugo Ratier, Villeros y villas miseria (Buenos Aires: Centro Editor de América Latina, 1971); María Eva Camelli and Valeria Snitcofsky, "La 'villa' de Buenos Aires: Génesis, construcciones y sentidos de un término," Café de las ciudades 11, no. 122/123 (December 2012); Massidda, "Plan de Emergencia."

12 Author's translation, Comisión Nacional de la Vivienda, Plan de Emergencia, 43-44.

13 Dávolos, Jabbaz, and Molina, Movimiento; Valeria Snitcofsky, "Villas de Buenos Aires y conflictos portuarios bajo el gobierno de Onganía: Aportes para un análisis de la articulación entre sindicalismo de base y organización territorial," in $L a$ clase trabajadora argentina en el siglo XX: experiencias de lucha y organización, ed. Victoria Basualdo (Buenos Aires: Cara o Ceca, 2011), 51-80; Alicia Ziccardi, Políticas de vivienda y movimientos urbanos: El caso de Buenos Aires (1963-1973) (Buenos Aires: Centro de Estudios Urbanos y Regionales, Instituto Torcuato di Tella, 1977), 127-136.

14 See "Villa Lugano, barrio proletario que avanza merced al esfuerzo vecinal: En el barrio Villa Cildáñez," La Hora, October 19, 1958; "Brutal atropello policial en Villa Cildáñez," Nuestra Palabra, February 4, 1964; Comisión Municipal de la Vivienda, Plan Piloto para Erradicación de Villas de Emergencia: Villas de emergencia $n^{\circ}$ 5-6-18 (Buenos Aires: Municipalidad de la Ciudad de Buenos Aires, 1966), 5-9, 23-29, 46-49, and also 2-60, generally; "Lugano: Villa No 6 Cildáñez," La Voz de las Villas, August 1969, 4; "Lugano - Villa No 8 (Ricchieri y Escalada)," La Voz de las Villas, April 1970, 4.

15 Michael A Burdick, For God and Fatherland: Religion and Politics in Argentina (Albany: SUNY Press, 1996), 142.

16 de Riz, and Torre, "Argentina," 73-101, 138-141; James, Resistance, 221-223; Richard Gillespie, Soldiers of Peron: Argentina’s Montoneros (Oxford: Clarendon, 1982).

17 Homero Saltalamacchia, Lucio Navarro, Vicente del Hoyo, Mario Santella, and Ana Azzarri (all members of the interdisciplinary design team or closely related to it) were interviewed by Romina Barrios in 2011; see Barrios, "Participación," 85-92.

18 IA-EcoSoc, Problems of Housing of Social Interest (Washington DC: Pan-American Union, 1954), 56; Adrián Gorelik, "Miradas cruzadas: El viaje latinoamericano del planning norteamericano," Bifurcaciones 1, no. 18 (2014): 1-20.

19 IA-EcoSoc. Problems of Housing of Social Interest, 56.

20 For a summary of the history of inter-American systems from the late nineteenth century to the 1990s, see the introduction of G. Pope Atkins's Encyclopedia of the Inter-American System (Greenwood Press: London, 1997). Atkin's encyclopedia is also helpful for those interested in a comprehensive list and brief descriptions of inter-American programs and agencies.

21 United Nations Economic and Social Council, "Co-ordination with the InterAmerican Economic and Social Council: Note by the Secretariat," presented at the 7th Session of the Economic Commission for Latin America, Las Paz, Bolivia, 


\section{Amps}

May 15, 1958, 7; NPA Special Policy Committee on Technical Cooperation, Technical Cooperation in Latin America: Recommendations for the Future (Washington: National Planning Association, 1956), 64. For a history on the emergence of the inter-American system, see Juan Pablo Scarfi, "In the Name of the Americas: The Pan-American Redefinition of the Monroe Doctrine and the Emerging Language of American International Law in the Western Hemisphere, 1898-1933," Diplomatic History 40, no. 2 (2016): 189-218.

22 Juan Molina y Vedia, La ciudad dulce: arquitecto Ernesto Vautier, 1898-1988 (Buenos Aires: Nobuko, 2010), 89-95; Alicia Novick, "Vautier, Ernesto," in Diccionario de Arquitectura en la Argentina, ed. Jorge Francisco Liernur and Fernando Aliata, vol. 6 (Buenos Aires: Clarín, 2004), 145-48.

23 Gorelik, "Miradas cruzadas," 13.

24 IA-EcoSoc, Problems of Housing of Social Interest.

25 John Cabot to John Foster Dulles, Washington, January 13, 1954,"Memorandum by the Assistant Secretary of State for Inter-American Affairs (Cabot) to the Secretary of State," in Foreign Relations of the United States, 1952-1954, The American Republics, vol. IV, Document 66, 362/1-1354 (Washington: US Government Printing Office, 1983); "Report Prepared in the Department of State," Washington, April 1954, in Foreign Relations of the United States, 1952-1954, The American Republics, vol. IV, OAS files, Lot 60 D 665, "Post-conferencedelegation report" (Washington: US Government Printing Office, 1983).

26 Organization of American States, "The Charter of Punta Del Este: Establishing an Alliance for Progress Within the Framework of Operation Pan America; August 17, 1961,” 1961, accessed July 27, 2017, http://avalon.law.yale.edu/20th_century/ intam16.asp\#1; Jeffrey Taffet, Foreign Aid as Foreign Policy: The Alliance for Progress in Latin America (London: Routledge, 2007); Gregorio Selser, Alianza para el progreso: La mal nacida (Buenos Aires: Iguazú, 1964).

27 Atkins, Encyclopedia, 16-19.

28 Ley 6.707 (Provincia de Buenos Aires) 1962, 707; For more about the Alliance for Progress, see René Longoni, Juan Carlos Molteni, and Virginia Edith Galcerán, "El monobloque: Notas para una arqueología de la vivienda social bonaerense" (unpublished manuscript, 2011); Antonio Ricchezza, Autoconstrucción: Esfuerzo propio, ayuda mutua: un sueño o una realidad? (Buenos Aires: Dunken, 2002).

29 Ley 6.707; Ricchezza, Autoconstrucción, 23-32; See Ley N 469 (Provincia de Buenos Aires) 1956 for information regarding the establishment of the Instituto de la Vividenda de la Provincia de Buenos Aires.

30 Ana Azzarri, interviewed by Barrios in 2011; see Barrios, "Participación," 74-76.

31 René Longoni et al., "El Departamento de Arquitectura UNLP. Primeros egresados. Primeras obras," paper presented at Jornadas de Investigación de la Facultad de Arquitectura y Urbanismo de La Plata (La Plata, 2009); Martin Carranza, "Innovaciones en la enseñanza: El desembarco de los talleres verticales en arquitectura (1955-1966)," in Tridecaedro: Jóvenes investigadores en ciencias sociales de la UNLP, ed. María de la Paz Echeverría and Pamela Vestfrid (La Plata: Universidad Nacional de La Plata, 2010), 25-43.

32 Ibid. 
33 For background information on Team 10, see Alison Smithson, ed., Team 10 Primer (Cambridge: MIT Press, 1968).

34 Anahi Ballent, "Learning from Lima. Previ, Perú: Habitar popular, vivienda masiva y debate arquitectónico, 1945-1970," in 'Tercer Mundo', special issue, Block 6 (2004): 86-95.

35 John F. C. Turner, Housing by People: Towards Autonomy in Building Environments (London: Marion Boyars, 1976).

36 Raúl Fernández Wagner, "Los asentamientos informales como cuestión: Revisión de algunos debates," in Los mil barrios (in)formales: Aportes para la construcción de un observatorio del hábitat popular del Área Metropolitana de Buenos Aires, ed. María Cristina Cravino (Los Polvorines: Instituto del Conurbano, Universidad Nacional de General Sarmiento, 2008), 13-44.

37 Camelli, 'Politicidad villera: El Movimiento Villero Peronista, 1973-1976" (PhD thesis, Universidad de Buenos Aires, 2013).

38 Dávolos, Jabbaz, and Molina, Movimiento.

39 Massidda, "The Plan de Emergencia," 42-51.

40 "Barrio Justo Suárez: Plan Piloto Realojamiento Villa 7," Trama 1, no. 3 (March 1982), 10-20; Marcos Winograd, "Subcomisión Hábitat," in Subcomisión Hábitat S.C.A. Núcleo Habitacional Transitorio 'Los Pinos': Rehabilitación del 'hábitat'. Informe 1ra etapa - 1982 (Buenos Aires: Sociedad Central de Arquitectos, 1982), 1-9; Barrios, "Participación," 120-131.

41 Larissa Adler de Lomnitz, Networks and Marginality: Life in a Mexican Shantytown (New York: Academic Press, 1977).

42 "Villeros peronistas, unidos y organizados hacia la liberación," El Descamisado 24 (October 30, 1973); “Lo que se viene,” El Descamisado 37 (January 29, 1974); Camelli, "Politicidad villera," 137, 143, 159, 170, 210, and 213.

43 Enrique Ibáñez, interviewed by Barrios in 2011; see Barrios, "Participación," 139-140.

44 Ana Azzarri, interviewed by Barrios in 2011; see Barrios, "Participación," 144-146.

45 John F. C. Turner, ed., "Dwelling Resources in South America," special issue, Architectural Design 8, (1963); Turner, Housing by People; Giancarlo de Carlo, "Architecture's Public," lecture originally delivered in 1969 and reproduced, in a re-edited and translated version, in Architecture and Participation, ed. Peter Blundell Jones, Doina Petrescu, and Jeremy Till (London: Spon Press, 2005), 3-22; Camillo Boano and Emily Kelling, "Towards an Architecture of Dissensus: Participatory Urbanism in South-East Asia," Footprint 7, no. 13 (2013): 41-62. These are, however, just a few examples. A library catalogue search of "participatory design" sheds light on the scope of the current discussion.

46 Alejandro Aravena and Andrés Iacobelli, Elemental: Incremental Housing and Participatory Design Manual (Ostfildern: Hatje Cantz, 2012); Nishat Awan, Tatjana Schneider and Jeremy Till, Spatial Agency: Other Ways of Doing Architecture (Hoboken: Taylor and Francis, 2013).

47 Emilio Pradilla, “Autoconstrucción, explotación de la fuerza de trabajo y políticas de estado en América Latina," in Ensayos sobre el problema de la vivienda 


\section{Amps}

en América Latina, ed. Emilio Pradilla (Mexico City: Universidad Autónoma Metropolitana, Unidad Xochimilco, 1982); Rod Burgess, "Petty Commodity Housing or Dweller Control? A Critique of John Turner's Views on Housing Policy," World Development 6, no. 9 (1978): 1105-1133.

48 Nuestra Arquitectura 44, no. 488 (1973).

49 Dávolos, Jabbaz, and Molina, Movimiento; Miguel Álvarez interviewed by Adriana Laura Massidda, July 22, 2014.

50 Blundell Jones, Petrescu, and Till, Architecture and Participation.

\section{Acknowledgments}

I would like to acknowledge Aya Alphs, René Longoni, Juan Molina y Vedia, Rosa Aboy, and Romina Barrios for their extraordinary feedback and guidance when I approached this topic. This paper would not have been possible without the ideas exchanged with them.

\section{Bibliography}

Aboy, Rosa "The Right to a Home': Public Housing in Post-World War II Buenos Aires," Journal of Urban History 33 (2007): 493-518.

Acta n ${ }^{\circ}$ 111/70 (Comisión Municipal de la Vivienda). 1970.

Álvarez, Miguel. Interviewed by Adriana Laura Massidda, July 22, 2014.

Aravena, Alejandro, and Andrés Iacobelli. Elemental: Incremental Housing and Participatory Design Manual. Ostfildern: Hatje Cantz, 2012.

Atkins, G. Pope. Encyclopedia of the Inter-American System. Greenwood Press: London, 1997.

Awan, Nishat, Tatjana Schneider, and Jeremy Till. Spatial Agency: Other Ways of Doing Architecture. Hoboken: Taylor and Francis, 2013.

Ballent, Anahi. Las huellas de la política: Vivienda, ciudad, peronismo en Buenos Aires, 1943-1955. Buenos Aires: Universidad Nacional de Quilmes/Prometeo, 2005.

Ballent, Anahi. "Learning from Lima. Previ, Perú: Habitar popular, vivienda masiva y debate arquitectónico, 1945-1970". In "Tercer Mundo," special issue, Block 6 (2004): 86-95.

“Barrio Justo Suárez: Plan Piloto Realojamiento Villa 7'. Trama 1, no. 3 (March 1982): $10-20$.

Barrios, Romina. "Participación y hábitat popular. Análisis de una experiencia piloto: El Plan de Realojamiento de la Villa 7 en Mataderos, Ciudad de Buenos Aires, entre 1971 y 1975." Master's thesis, Universidad de Buenos Aires, 2011.

Bellardi, Marta, and Aldo de Paula. Villas miseria: origen, erradicación y respuestas populares. Buenos Aires: Centro Editor de América Latina, 1986.

Blaustein, Eduardo. Prohibido vivir aquí: Una historia de los planes de erradicación de villas de la última dictadura. Buenos Aires: Comisión Municipal de la Vivienda, 2001.

Blundell Jones, Peter, Doina Petrescu, and Jeremy Till. Architecture and Participation. London: Spon Press, 2005. 


\section{Amps}

Boano, Camillo, and Emily Kelling. "Towards an Architecture of Dissensus: Participatory Urbanism in South-East Asia.” Footprint 7, no. 13 (2013): 41-62.

"Brutal atropello policial en Villa Cildáñez.” Nuestra Palabra, February 4, 1964.

Burdick, Michael A. For God and Fatherland: Religion and Politics in Argentina. Albany: SUNY Press, 1996.

Burgess, Rod. "Petty Commodity Housing or Dweller Control? A Critique of John Turner's Views on Housing Policy." World Development 6, no. 9 (1978): 1105-1133.

Cabot, John. Washington, January 13, 1954, "Memorandum by the Assistant Secretary of State for Inter-American Affairs (Cabot) to the Secretary of State." In Foreign Relations of the United States, 1952-1954, The American Republics, vol. IV, Document 66, 362/1-1354 (Washington: US Government Printing Office, 1983. http://history.state.gov/historicaldocuments/frus1952-54v04/d66).

Camelli, Eva, and Valeria Snitcofsky. "La 'villa' de Buenos Aires: Génesis, construcciones y sentidos de un término." Café de las ciudades 11, no. 122/123 (December 2012).

Camelli, María Eva. "Politicidad villera: El Movimiento Villero Peronista, 19731976." PhD thesis, Universidad de Buenos Aires, 2013.

Carranza, Martín. "Arquitectura, movimiento estudiantil y los espacios de la FAU-UNLP (1966-1973)." In III Jornadas de Estudio y Reflexión sobre el Movimiento Estudiantil Argentino. La Plata: Universidad Nacional de La Plata, 2010.

Carranza, Martín. "Innovaciones en la enseñanza: El desembarco de los talleres verticales en arquitectura (1955-1966)." In Tridecaedro: Jóvenes investigadores en ciencias sociales de la UNLP, edited by María de la Paz Echeverría and Pamela Vestfrid. La Plata: Universidad Nacional de La Plata, 2010.

Cedrón, Osvaldo. "Villa 7 - Plan Piloto de Realojamiento: balance de una experiencia." In "El techo," special issue, Revista de Arquitectura 198 (2000): 108-111.

Comisión Intervillas - Zona Retiro. Escuela “Bandera Argentina.” June 1964.

Comisión Municipal de la Vivienda. Vol. 1 of Centro Urbano Integrado Parque Almirante Brown: Solicitud de préstamo al Banco Interamericano de Desarrollo. Buenos Aires: Municipalidad de la Ciudad de Buenos Aires, 1965.

Comisión Municipal de la Vivienda. "C.M.V. Villas de Emergencia.” 1970.

Comisión Municipal de la Vivienda. Plan Piloto para Erradicación de Villas de Emergencia: Villas de emergencia $n^{\circ}$ 5-6-18. Buenos Aires: Municipalidad de la Ciudad de Buenos Aires, 1966.

Comisión Nacional de la Vivienda. Plan de Emergencia: Informe elevado al Poder Ejecutivo Nacional. Buenos Aires: Ministerio de Trabajo y Previsión, 1956.

Comisión Nacional de la Vivienda. Informe de la Comisión Nacional de la Vivienda sobre su actuación y Plan Integral elevado al Ministerio de Trabajo y Previsión, vol. 1 Buenos Aires: Ministerio de Trabajo y Previsión, 1957.

Dávolos, Patricia, Marcela Jabbaz, and Estela Molina. Movimiento villero y estado (1966-1976). Buenos Aires: Centro Editor de América Latina, 1987.

de Lomnitz, Larissa Adler. Networks and Marginality: Life in a Mexican Shantytown. New York: Academic Press, 1977. 


\section{Amps}

de Riz, Liliana, and Juan Carlos Torre. “Argentina since 1946.” In The Cambridge History of Latin America, vol. VIII, edited by Leslie Bethell, 73-101. Cambridge: Cambridge University Press, 1991.

"Desalojos: Última hazaña de la dictadura." El Descamisado 2 (May 29, 1973).

"Entrevistose con el intendente la Comisión de la Vivienda." La Hora. September 14, 1958.

“¡Esas casas son suyas! Ocupantes del Barrio Almirante Brown.” Nuestra Palabra (March 5, 1963).

Gillespie, Richard. Soldiers of Peron: Argentina's Montoneros. Oxford: Clarendon, 1982.

Gorelik, Adrián. "Miradas cruzadas: El viaje latinoamericano del planning norteamericano." Bifurcaciones, no. 18 (2014): 1-20.

IA-EcoSoc. Problems of Housing of Social Interest. Washington DC: Pan-American Union, 1954.

Instituto Histórico de la Ciudad de Buenos Aires. Cronista Mayor de Buenos Aires 4, no. 33 (August 2002).

James, Daniel. Resistance and Integration: Peronism and the Argentine Working Class, 1946-1976. Cambridge: Cambridge University Press, 1994.

La Voz de las Villas. February 1965.

Ley 6.707 (Provincia de Buenos Aires). 1962.

Ley No 469 (Provincia de Buenos Aires). 1956.

"Lo que se viene." El Descamisado 37 (January 29, 1974).

Longoni, René, Virginia Edith Galcerán, Juan Carlos Molteni, Roxana Pérez, Martín Carranza, Ignacio Fonseca, and Carolina Bottega. "El Departamento de Arquitectura UNLP. Primeros egresados. Primeras obras." Paper presented at Jornadas de Investigación de la Facultad de Arquitectura y Urbanismo de La Plata. La Plata, 2009.

Longoni, René, Juan Carlos Molteni, and Virginia Edith Galcerán. "El monobloque:

Notas para una arqueología de la vivienda social bonaerense." Unpublished manuscript, 2011.

“Lugano: Villa No 6 - Cildáñez.” La Voz de las Villas, August 1969, 4.

"Lugano - Villa No 8 (Ricchieri y Escalada).” La Voz de las Villas, April 1970, 4.

Massidda, Adriana Laura. "Mapping the Suburbs: Cartographic Representations of Villa Celina, Buenos Aires, 1955-2011." In New Suburban Stories, edited by Martin Dines and Timotheus Vermeulen, 17-30. London: Bloomsbury-Continuum, 2013. Massidda, Adriana Laura. "The Plan de Emergencia (1956): Housing Shortage in Buenos Aires Then and Now." Scroope: The Cambridge Architecture Journal 21 (2012): 42-51.

Massidda, Adriana Laura. "Utopian Visions for Buenos Aires Shantytowns: Collective Imaginaries of Housing Rights, Upgrading and Eviction (1956-2013)." Bulletin of Latin American Research (2016).

Adriana Massidda, "Urban Planning and Undertakings upon Informal Settlements in Buenos Aires: A 1955-1959 Review.” MPhil thesis, University of Cambridge, 2011.

Ministerio de Bienestar Social. Plan de Erradicación de las Villas de Emergencia de la Capital Federal y el Gran Buenos Aires: Primer programa-erradicación y alojamiento transitorio. 1968. 


\section{Amps}

Molina y Vedia, Juan. La ciudad dulce: Arquitecto Ernesto Vautier, 1898-1988. Buenos Aires: Nobuko, 2010.

Novick, Alicia. "Vautier, Ernesto." In Diccionario de Arquitectura en la Argentina, vol. 6, edited by Jorge Francisco Liernur and Fernando Aliata, 145-148. Buenos Aires: Clarín, 2004.

NPA Special Policy Committee on Technical Cooperation, Technical Cooperation in Latin America: Recommendations for the Future. Washington: National Planning Association, 1956.

Nuestra Arquitectura 44, no. 483 (March 1973).

Organization of American States. "The Charter of Punta Del Este, Establishing an Alliance for Progress Within the Framework of Operation Pan America; August 17, 1961.” 1961. Accessed July 29, 2017. http://avalon.law.yale.edu/20th_century/intam16.asp\#1.

"Para construir las casas de los villeros nadie mejor que el pueblo villero." El Descamisado 32 (December 24, 1973).

Pieterse, Edgar. "Notes towards an Alternative Framework for Urban Development." In African Perspectives - [South] Africa, edited by Gerhard Bruyns and Arie Graafland, 50-63. Rotterdam: 010 Publishers, 2012.

"Plan Piloto de Realojamiento Barrio de Emergencia No 7." Nuestra Arquitectura 44, no. 488 (1973): 28-32.

Pradilla, Emilio. "Autoconstrucción, explotación de la fuerza de trabajo y políticas de Estado en América Latina.” In Ensayos sobre el problema de la vivienda en América Latina, edited by Emilio Pradilla, pp-pp. Mexico City: Universidad Autónoma Metropolitana, Unidad Xochimilco, 1982. <pages plse>

"Presentan en Lanús el pedido para mejorar los barrios de emergencia." La Hora. May 9, 1958.

Ratier, Hugo. Villeros y villas miseria. Buenos Aires: Centro Editor de América Latina, 1971.

"Report Prepared in the Department of State." Washington, April 1954. In Foreign Relations of the United States, 1952-1954, The American Republics, vol. IV, OAS files, Lot 60 D 665, "Post-conference-delegation report." Washington: US Government Printing Office, 1983. Accessed July 28, 2017. http://history.state.gov/historicaldocuments/frus1952-54v04/d78.

Resolución Municipal 14.447. Boletín Municipal de la Ciudad de Buenos Aires 10,923 (1958).

Resolución Municipal 15.694. H. Concejo Deliberante [MCBA] (1959).

Resolución Municipal 16.597. Boletín Municipal de la Ciudad de Buenos Aires 11,448 (1960).

Resolución Municipal 17.231. Boletín Municipal de la Ciudad de Buenos Aires 11,543 (1960).

Resolución Municipal 17.497. Boletín Municipal de la Ciudad de Buenos Aires 11,621 (1961).

Ricchezza, Antonio. Autoconstrucción: Esfuerzo propio, ayuda mutua: un sueño o una realidad? Buenos Aires: Dunken, 2002.

Scarfi, Juan Pablo. "In the Name of the Americas: The Pan-American Redefinition of the Monroe Doctrine and the Emerging Language of American International 


\section{Amps}

Law in the Western Hemisphere, 1898-1933. Diplomatic History 40, no. 2 (2016): $189-218$.

Selser, Gregorio. Alianza para el progreso: La mal nacida. Buenos Aires: Iguazú,1964. Simone, AbdouMaliq. "Reclaiming Black Urbanism: Inventive Methods for Engaging Urban Fields in Africa and beyond." In African Perspectives - [South] Africa, edited by Gerhard Bruyns and Arie Graafland. 30-49. Rotterdam: 010 Publishers, 2012.

Smithson, Alison, ed. Team 10 Primer. Cambridge, Mass: MIT Press, 1968.

Snitcofsky, Valeria. "Villas de Buenos Aires y conflictos portuarios bajo el gobierno de Onganía: aportes para un análisis de la articulación entre sindicalismo de base y organización territorial." In La clase trabajadora argentina en el siglo $X X$ : experiencias de lucha y organización, edited by Victoria Basualdo, 51-80. Buenos Aires: Cara o Ceca, 2011.

Summa. no. 36 (1971).

Summa. no. 72 (1974).

Taffet, Jeffrey. Foreign Aid as Foreign Policy: The Alliance for Progress in Latin America. London: Routledge, 2007.

Turner, John F. C. Housing by People: Towards Autonomy in Building Environments. London: Marion Boyars, 1976.

Turner, John F. C., ed. "Dwelling Resources in South America'." Special issue, Architectural Design 8 (1963).

United Nations Economic and Social Council. "Co-ordination with the InterAmerican Economic and Social Council: Note by the Secretariat." Presented at the 7th Session of the Economic Commission for Latin America, Las Paz, Bolivia, May 15, 1958.

"Villa Lugano, barrio proletario que avanza merced al esfuerzo vecinal: En el barrio Villa Cildáñez.” La Hora, October 19, 1958.

"Villeros peronistas, unidos y organizados hacia la liberación." El Descamisado 24 (October 30, 1973).

Wagner, Raúl Fernández. "Los asentamientos informales como cuestión: Revisión de algunos debates." In Los mil barrios (in)formales: Aportes para la construcción de un observatorio del hábitat popular del Área Metropolitana de Buenos Aires, edited by María Cristina Cravino, 13-44. Los Polvorines: Instituto del Conurbano, Universidad Nacional de General Sarmiento, 2008.

Winograd, Marcos. "Subcomisión Hábitat." In Subcomisión Hábitat S.C.A. Núcleo Habitacional Transitorio "Los Pinos". Rehabilitación del 'hábitat'. Informe Ira etapa - 1982. Buenos Aires: Sociedad Central de Arquitectos, 1982.

Yujnovsky, Oscar. Claves políticas del problema habitacional argentino (1955-1981). Buenos Aires: Grupo Editorial Latinoamericano, 1984.

Ziccardi, Alicia. Políticas de vivienda y movimientos urbanos: El caso de Buenos Aires (1963-1973). Buenos Aires: Centro de Estudios Urbanos y Regionales, Instituto Torcuato di Tella, 1977.

Ziccardi, Alicia. "El tercer gobierno peronista y las villas miseria de la ciudad de Buenos Aires (1973-1976).” Revista Mexicana de Sociología 4 (46) (1984): 145-72. 